\title{
Indium 111 autologous leucocyte scanning in lobar pneumonia and lung abscesses
}

\author{
SETHNA H SAVERYMUTTU, GARETH PHILLIPS, A MICHAEL PETERS, \\ J PETER LAVENDER \\ From the Departments of Medicine and Diagnostic Radiology, Royal Postgraduate Medical School, \\ Hammersmith Hospital, London
}

ABSTRACT Indium 111 leucocyte scanning was used to examine the kinetics of granulocyte localisation in five patients with lobar pneumonia and four patients with lung abscess. Lung abscesses showed dense accumulation of labelled granulocytes within four hours of injection. In contrast, in all cases of lobar pneumonia granulocytes failed to accumulate over a period of up to 24 hours despite evidence of adequate perfusion and of uptake in inflammation elsewhere. These results suggest that the recruitment of granulocytes to lobar pneumonia may be terminated early in its clinical course.

Indium $111\left({ }^{111}\right.$ In) autologous leucocyte scanning has been extensively used for localisation of intraabdominal abscesses. ${ }^{12}$ More recently the potential for studying other conditions with an inflammatory component has been developed. For instance, the technique has been used to demonstrate the kinetics of labelled leucocytes in inflamed bowel. After injection ${ }^{111}$ In labelled leucocytes migrate to and accumulate in diseased bowel within a matter of minutes, pass into the bowel lumen over the following few hours, and are subsequently excreted over the next four days. ${ }^{3-6}$

Address for reprint requests: Dr SHS Saverymuttu, Medicine II, St George's Hospital Medical School, London SW17B.

Accepted 24 June 1985
Unlike an intra-abdominal abscess, but like bowel, the parenchyma of the lung provides a portal of exit for granulocytes when it is inflamed. This is reflected by the presence of granulocytes in sputum, analogous to faecal granulocytes in inflammatory bowel disease. The aim of this study therefore was to examine the kinetics of granulocyte localisation in lobar pneumonia and in lung abscess to see how far they resembled or differed from the kinetics in inflammatory bowel disease.

\section{Method}

Nine patients were studied, five with lobar pneumonia and four with lung abscess. The clinical details are

Table 1 Details of the patients

\begin{tabular}{|c|c|c|c|c|c|c|c|c|}
\hline \multirow[t]{2}{*}{ Patient } & \multirow{2}{*}{$\begin{array}{l}\text { Age } \\
(y)\end{array}$} & \multirow[t]{2}{*}{ Diagnosis } & \multirow{2}{*}{$\begin{array}{l}\text { Associated } \\
\text { condition }\end{array}$} & \multirow{2}{*}{$\begin{array}{l}\text { Sputum } \\
\text { culture }\end{array}$} & \multirow{2}{*}{$\begin{array}{l}\text { Sputum } \\
\text { leucocytes }\end{array}$} & \multirow{2}{*}{$\begin{array}{l}\text { White cell } \\
\text { count } \\
\left(\times 10^{5} / l\right)\end{array}$} & \multicolumn{2}{|c|}{ Duration (days) before scan } \\
\hline & & & & & & & Treatment & Symptoms \\
\hline $\begin{array}{l}1 \\
2 \\
3\end{array}$ & $\begin{array}{l}68 \\
57 \\
71\end{array}$ & $\begin{array}{l}\text { Lung abscess } \\
\text { Lung abscess } \\
\text { Lung abscess }\end{array}$ & $\begin{array}{l}\text { Diabetes } \\
\text { Renal failure } \\
\text { Bronchogenic } \\
\quad \text { carcinoma }\end{array}$ & $\begin{array}{l}\text { Proteus } \\
\text { Klebsiella } \\
\text { E coli }\end{array}$ & $\begin{array}{l}+ \\
+ \\
+\end{array}$ & $\begin{array}{l}11 \\
17.6 \\
10.6\end{array}$ & $\begin{array}{r}10 \\
12 \\
1\end{array}$ & $\begin{array}{r}16 \\
19 \\
8\end{array}$ \\
\hline $\begin{array}{l}4 \\
5\end{array}$ & $\begin{array}{l}78 \\
70\end{array}$ & $\begin{array}{l}\text { Lung abscess } \\
\text { Lobar } \\
\text { pneumonia }\end{array}$ & - & $\begin{array}{l}\text { E coli } \\
\text { Strep } \\
\quad \text { pneumoniae }\end{array}$ & $\begin{array}{l}+ \\
+\end{array}$ & $\begin{array}{l}14.5 \\
24\end{array}$ & $\begin{array}{l}1 \\
2\end{array}$ & $\begin{array}{l}8 \\
\text { Indefinite: vague } \\
\text { symptoms of } \\
\text { malaise } 2 \text { weeks }\end{array}$ \\
\hline 6 & 60 & $\begin{array}{l}\text { Lobar } \\
\text { pneumonia }\end{array}$ & - & $\begin{array}{l}\text { Strep } \\
\quad \text { pneumoniae }\end{array}$ & + & 18.6 & 2 & 2 \\
\hline 7 & 80 & $\begin{array}{l}\text { Lobar } \\
\text { pneumonia }\end{array}$ & - & $\begin{array}{l}\text { Strep } \\
\quad \text { pneumoniae }\end{array}$ & + & 8 & 1 & 2 \\
\hline 8 & 71 & $\begin{array}{l}\text { Lobar } \\
\text { pneumonia }\end{array}$ & $\begin{array}{l}\text { Chronic } \\
\text { Bronchitis }\end{array}$ & Normal flora & + & 7 & 2 & $\begin{array}{l}\text { Indefinite: vague } \\
\text { symptoms of } \\
\text { malaise } 4 \text { weeks }\end{array}$ \\
\hline 9 & 16 & $\begin{array}{l}\text { Lobar } \\
\text { pneumonia }\end{array}$ & Post-operative & - & 0 & 9.2 & 13 & $13^{\text {malaise } 4 \text { weeks }}$ \\
\hline
\end{tabular}


Table 2 Radiological features and detection of indium 111 in patients with lung abscess and patients with pneumonia

\begin{tabular}{|c|c|c|c|c|}
\hline \multirow[t]{2}{*}{ Patient No } & \multirow[t]{2}{*}{ Radiological site of abscess or pneumonia } & \multicolumn{3}{|c|}{ Time after injection of ${ }^{111}$ In granulocytes } \\
\hline & & $40 \min$ & $3 h$ & $15-24 h$ \\
\hline \multicolumn{5}{|l|}{ Abscess } \\
\hline 1 & $\mathbf{R}$ middle lobe & + & + & + \\
\hline 2 & $\mathrm{R}$ middle lobe & ND & + & + \\
\hline 3 & $\mathbf{R}$ lower and middle lobes & - & + & + \\
\hline 4 & L lower lobe & ND & + & + \\
\hline \multicolumn{5}{|l|}{ Pneumonia } \\
\hline 5 & $\mathbf{R}$ upper lobe & ND & - & + \\
\hline 6 & $\mathbf{R}$ middle lobe & - & - & - \\
\hline 7 & $\mathbf{R}$ middle lobe & - & - & - \\
\hline 8 & $\mathbf{R}$ middle lobe & - & - & - \\
\hline 9 & L lower lobe & - & - & - \\
\hline
\end{tabular}

R-right; L-left; ND—not done; + indicates radioactivity present and - radioactivity absent.

summarised in table 1. Autologous granulocytes were separated and labelled, without removal from plasma, as previously described. ${ }^{7}$ This method ensures that granulocyte indium 111 activity does not vary with peripheral count and that the artefactual pulmonary leucocyte sequestration seen after labelling in saline is avoided. The administered activity was about 200 $\mu \mathrm{Ci}$. Abdominal and chest scans were performed 40 minutes, 3-4 hours, and 24 hours after return of the labelled granulocytes and compared with radiological findings.

In some patients dynamic gamma camera imaging was performed over the lung fields immediately after injection. Time-activity curves based on symmetrical and similar sized regions of interest over normal and affected lung were constructed with a computer (MDS $\mathrm{A}^{2}$ ) on line to the gamma camera.

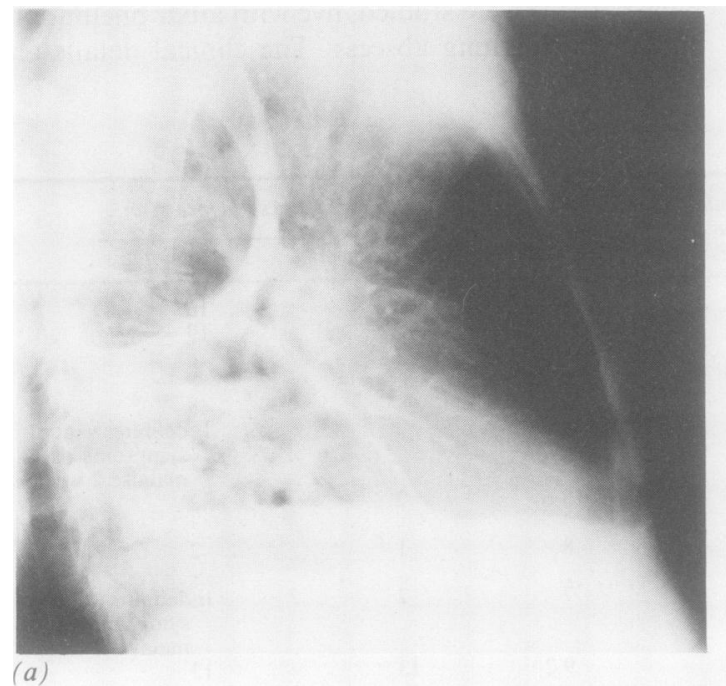

\section{Results}

The scanning and radiological findings are summarised in table 2 . In the four patients with lung abscesses, who were studied one to 12 days after continuous treatment with antibiotics, the chest radiograph showed evidence of cavitation (fig 1). Early scans were performed 40 minutes after return of the labelled granulocytes in two of the four patients. In one a focal area of increased activity corresponding to the site of the abscess was seen, while in the other the scan was normal. In all four patients later scans three to four hours and 24 hours after the return of the cells, were clearly positive over the abscess site (fig 2). Abdominal scans at 24 hours showed activity in the large bowel in three of the four, representing swallowed labelled granulocytes. Three of the four

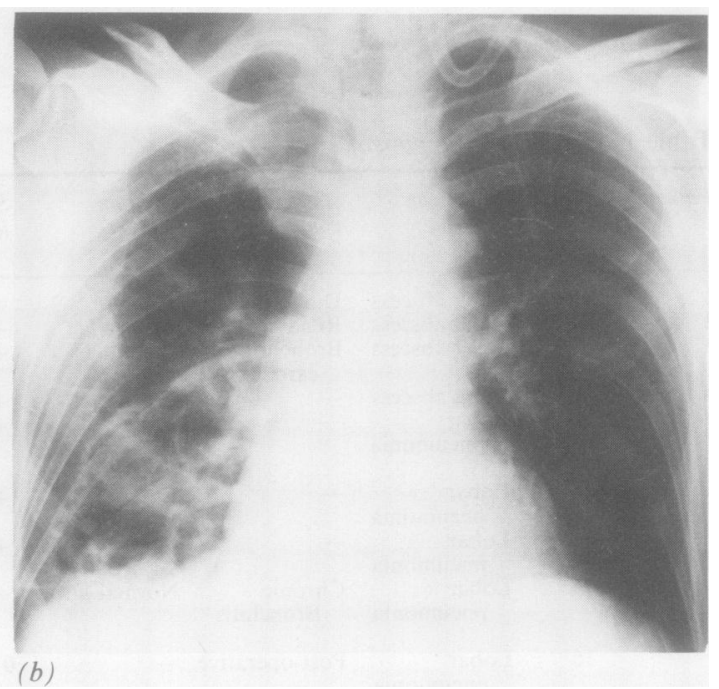

Fig 1 (a) Patient 2: Anteroposterior and (b) lateral chest radiographs showed a multiloculated abscess in the right lower lobe. 


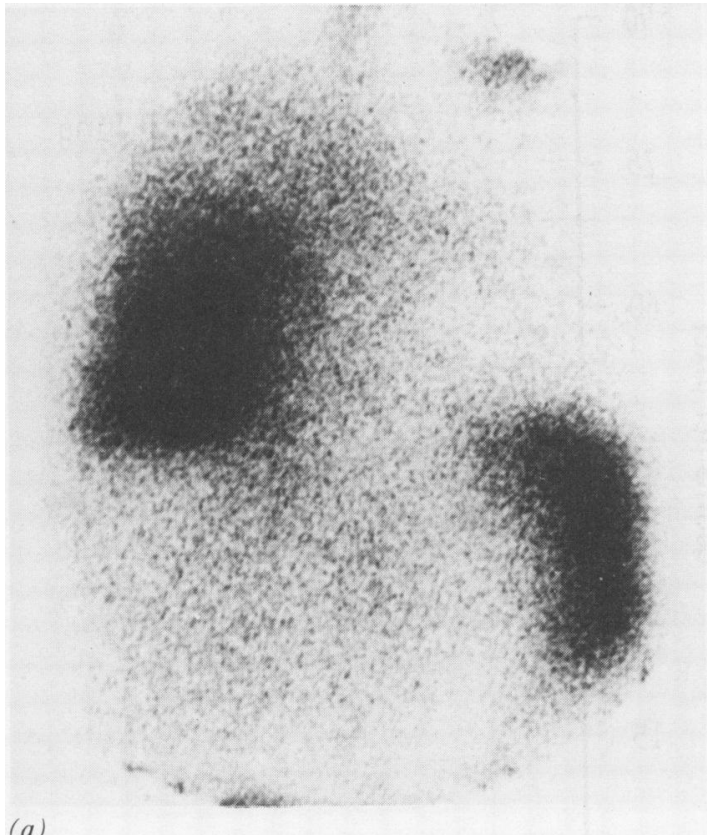

(a)

abscesses resolved with antibiotic treatment; the remaining patient died but necropsy was not performed. No repeat studies were performed.

All five cases of lobar pneumonia showed characteristic radiological changes (fig 3). Streptococcus pneumoniae was the cause in three patients. No

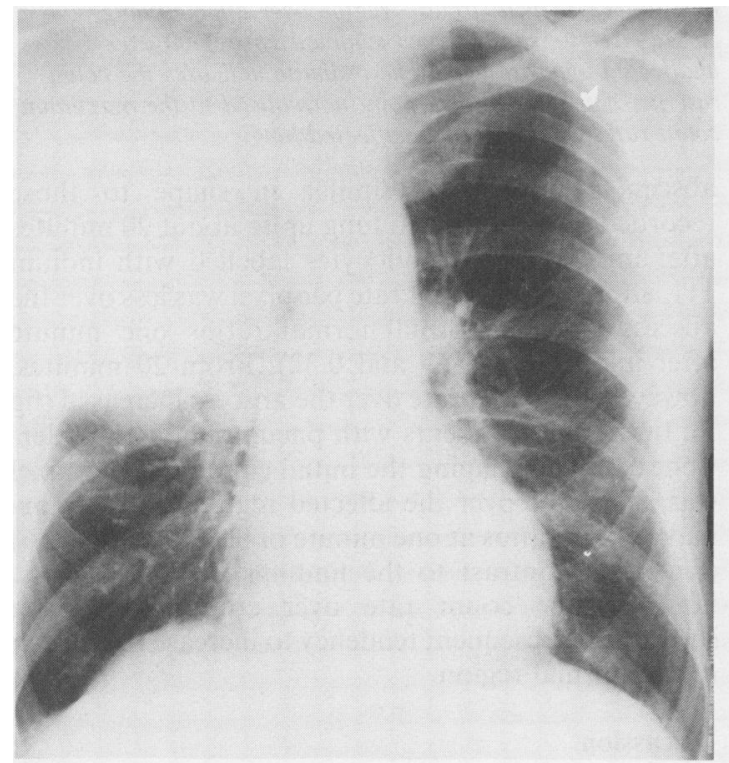

(a)

Fig 3 (a) Posteroanterior and (b) lateral chest radiographs of pat
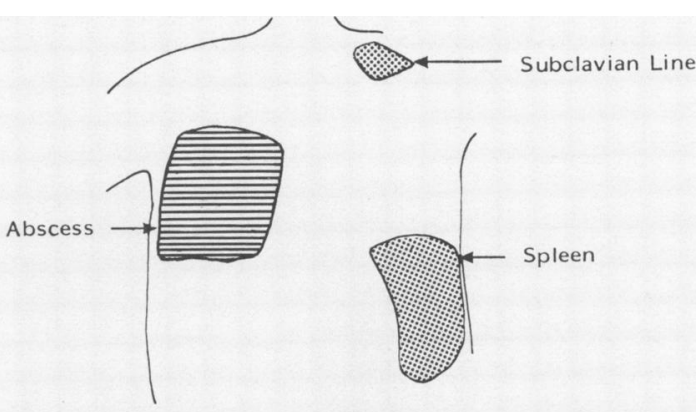

(b)

Fig 2 (a) White cell scan of the chest and upper abdomen of patient 2 showing focal uptake corresponding to the right lower lobe abscess. Other areas of focal uptake correspond to the spleen and subclavian lines respectively. Only faint activity is seen in the liver. (b) Diagram of white cell scan.

organism was isolated in the other two. The patients were studied one to 13 days after the start of antibiotic treatment, when all except one had leucocytes in the sputum. Scans were negative at the site of the pneumonia in all five cases at all times (fig 4). Furthermore, apart from splenic uptake and uptake in an infected

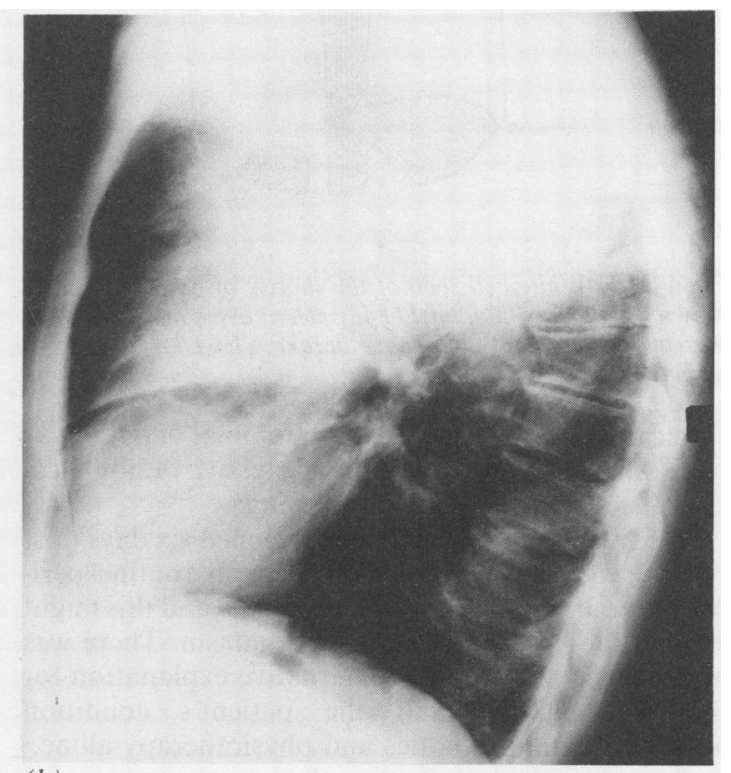

(b) 

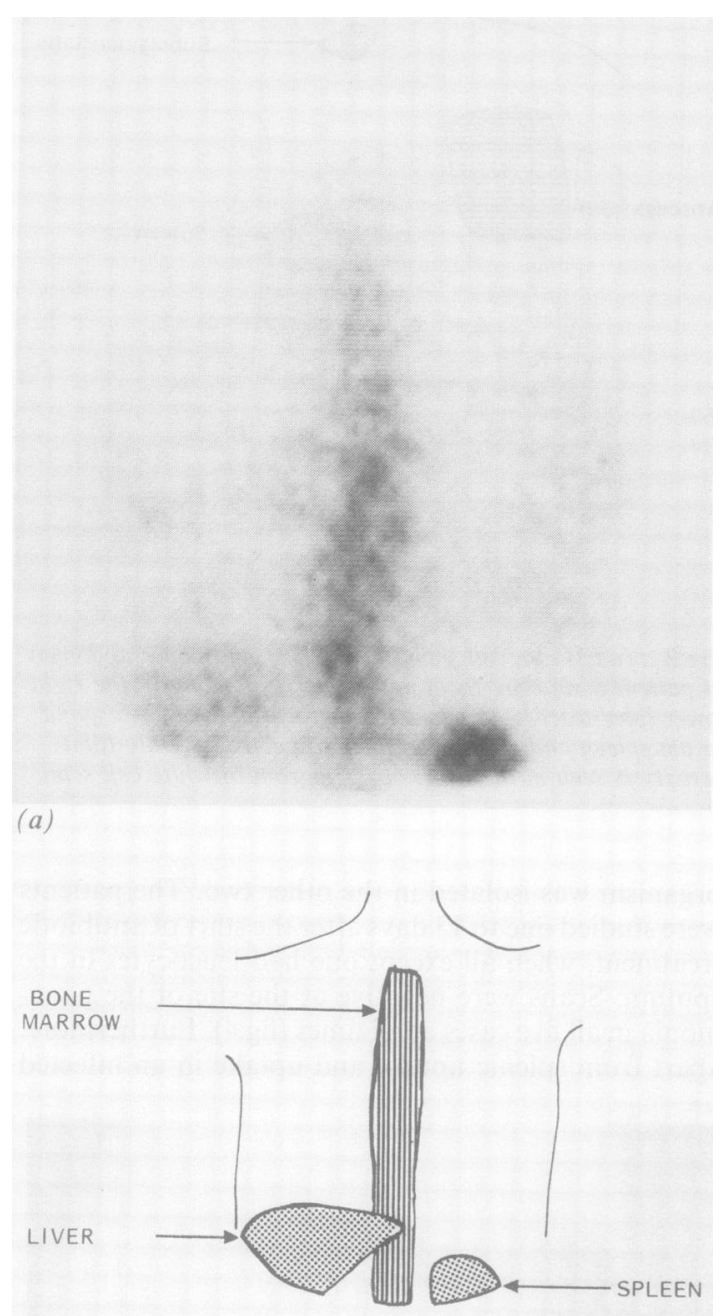

(b)

Fig 4 (a) White cell scan of the thorax of patient 5 showing uptake of indium 111 in spleen, liver, and bone marrow but no focal pulmonary uptake. (b) Diagram of white cell scan.

surgical wound in case 9 , no abdominal activity was seen. All five patients showed progressive radiological clearance from the time of scanning.

In patient 9 the pneumonia developed six days post operatively. This patient had been on routine perioperative antibiotics during that period and this might explain the failure to detect an organism. There was no evidence to suggest an alternative explanation for the consolidation and the patient's condition improved with antibiotics and physiotherapy alone.

On dynamic imaging in the two patients with abscess, the time-activity curves recorded over the

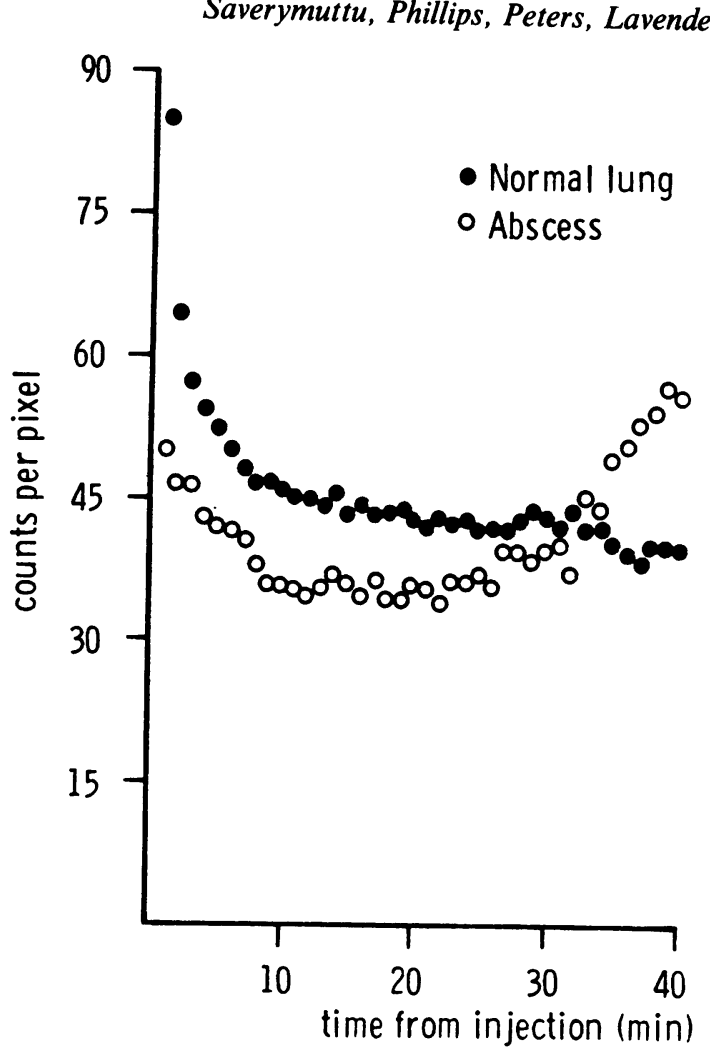

Fig 5 Time-activity curves recorded by dynamic gamma camera imaging anteriorly over the chest after injection of granulocytes labelled with indium 111 in a patient with a lung abscess. Open circles-region over affected lung; closed circles-similar sized symmetrical region over unaffected opposite lung. The ordinate indicates the count rate per computer matrix point normalised to the maximum count rate recorded over unaffected lung.

abscess regions were similar in shape to those recorded over unaffected lung up to about 20 minutes after injection of granulocytes labelled with indium 111 , although the count rate per pixel was less over the abscess (with abnormal:normal ratios one minute after injection of 0.59 and 0.32 ). From 20 minutes, however, the count rate over the abscess increased (fig 5). In the three patients with pneumonia who underwent dynamic imaging the initial count rate per pixel was again less over the affected region (with abnormal:normal ratios at one minute of $0.71,0.7$ and 0.66 ) (fig 6). In contrast to the findings in lung abscess, however, the count rate over consolidated lung showed no subsequent tendency to increase in relation to the normal region.

\section{Discussion}

The finding that ${ }^{111}$ In labelled granulocytes fail to 


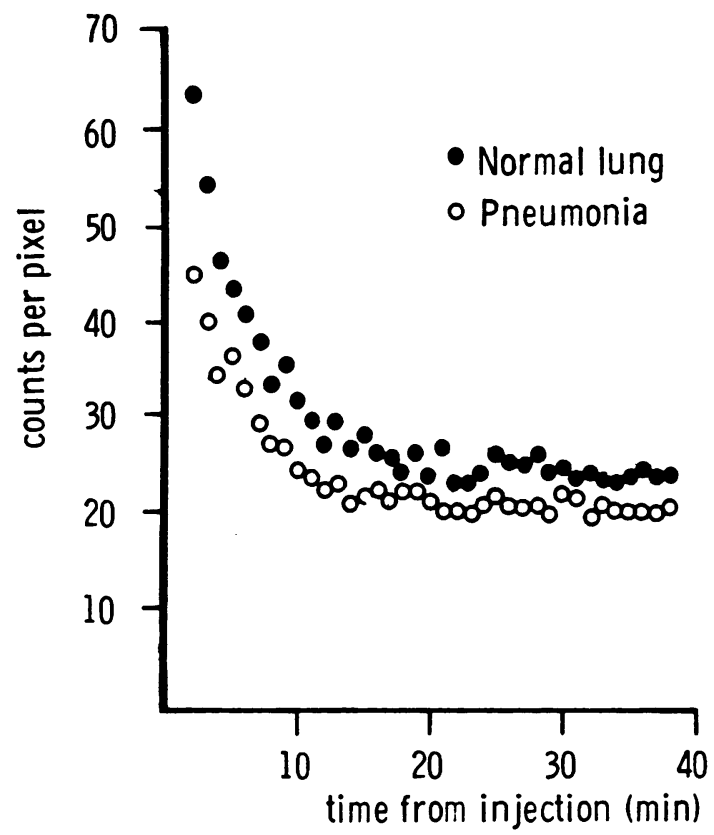

Fig 6 Time-activity curves recorded by dynamic gamma camera imaging anteriorly over the chest after injection of granulocytes labelled with indium 111 in a patient with lobar pneumonia. Open circles-region over affected lung; closed circles-similar sized symmetric region over unaffected opposite lung. The ordinate indicates the count rate per computer matrix point normalised to the maximum count rate recorded over unaffected lung.

\section{Discussion}

The finding that ${ }^{111}$ In labelled granulocytes fail to localise in lobar pneumonia is surprising particularly in view of the accumulating reports of the effectiveness of this technique in widely varying conditions. In addition to the well known uptake in abscess, recent studies have demonstrated visualisation by ${ }^{11}{ }^{1}$ In leucocyte scanning of ulcerative colitis, Crohn's disease, ${ }^{34}$ ischaemic bowel, ${ }^{8}$ osteomyelitis, ${ }^{9}$ pancreatitis, ${ }^{10}$ prosthetic vascular graft infection, ${ }^{11}$ and a renal transplant undergoing rejection. ${ }^{12}$ The number of false negative scans is very low in all such inflammatory lesions, suggesting that there is almost always migration of cells from the circulating pool.

Several explanations of our negative scans in lobar pneumonia are possible. Firstly, the cells may be damaged during the separation and labelling procedure. The technique used here, however, been shown to result consistently in normal granulocyte biodistribution and rapid accumulation in septic foci. ${ }^{513}$ Furthermore, in postoperative lobar pneumonia (case 9), the infected abdominal wound site was visualised, indicating normal migration to that focus.
Secondly, there may be appreciable impairment of perfusion, thereby limiting vascular access. Results of ventilation-perfusion scanning suggest, however, that there is adequate, though reduced, perfusion of consolidated lobes. ${ }^{14}$ Furthermore, the immediate signals from ${ }^{111}$ In labelled granulocyte achieved with dynamic imaging indicated that, although inflow was reduced in the affected regions, it was clearly not decreased sufficiently to produce any appreciable reduction in vascular access, and indeed not reduced to any greater extent than inflow into the abscess. Thirdly, although all patients with lobar pneumonia were receiving antibiotic treatment, previous studies have shown that this does not prevent localisation of ${ }^{111}$ In labelled granulocytes in inflammatory sites. ${ }^{12}$ Indeed, all of the patients with lung abscess were scanned while receiving antibiotic treatment.

A further possible explanation for these negative scans in lobar pneumonia is that recruitment of fresh leucocytes might have ceased before the injection of labelled granulocytes and that, whatever the intravescular kinetics of granulocytes, there was no extravascular granulocyte migration after this time. The presence of sputum leucocytes at the time of scanning is difficult to reconcile with this, in view of the short intravascular half life of granulocytes approximately about seven hours, and suggests that granulocytes have a considerable postmigration life span and that they are capable of remaining viable in lung parenchyma for some time. Evidence to support this implication has been lacking until recently, when Bueshcer et $a l^{15}$ were able to study granulocyte life span in a patient with chronic granulomatous disease receiving leucocyte transfusions for a chest infection. They showed that granulocytes were present in sputum for at least $\mathbf{4 2}$ hours after their disappearance from the blood. This suggests that granulocytes can be present in sputum for an appreciable time after the termination of granulocyte recruitment into an infective chest lesion.

We suggest that this last explanation is the most likely. Unlike other inflammatory conditions studied with ${ }^{111}$ In granulocytes, in lobar pneumonia there is no breakdown of tissue architecture and it is possible that the alveolar air spaces become filled with exudate soon after the onset of infection, so that further granulocytes are unable to gain access and recruitment ceases. The mechanism of cessation of recruitment could be mechanical but seems more likely to be due to biological factors. Uptake of ${ }^{111}$ In granulocytes into lobar pneumonia has been recorded in the dog within 24 hours of its induction. ${ }^{16}$ This stage of active granulocyte recruitment was probably completed in our cases before imaging. Indeed, in at least two patients with white cells were injected within 48 hours of the onset of pneumonia, suggesting that 
recruitment is terminated before this. Such a limited period of recruitment in lobar pneumonia may be contrasted with lung abscess, in which granulocyte migration into the septic focus continues pari passu with tissue destruction.

We are grateful to Miss Sally Barnes for typing this manuscript and to Miss Belinda Henderson and Miss Penny George for technical assistance.

\section{References}

1 McDougall I, Baumert J, Lantieri R. Evaluation of 111-indium leucocyte whole body scanning. $A J R$ 1979;133:849-54.

2 Coleman R, Black R, Welch D, Maxwell G. Indium-111labelled leucocytes in the evaluation of suspected abdominal abscesses Am J Surg 1980;139:99-104.

3 Segal A, Munro J, Ensell J, Sarner M. Indium-111tagged leucocytes in the diagnosis of inflammatory bowel disease. Lancet 1981;i:230-2.

4 Saverymuttu SH, Peters AM, Lavender JP, Hodgson HJF, Chadwick VS. 111-Indium autologous leucocytes in inflammatory bowel disease. Gut 1983;24:293-9.

5 Saverymuttu SH, Peters AM, Reavy HJ, Lavender JP. Measurement of granulocyte migration and accumulation in inflammation in man. Clin Exp Immunol 1983;52:607-12.

6 Saverymuttu SH, Peters AM, Lavender JP, Pepys MB, Hodgson HJF, Chadwick VS. Quantitative faecal 111-indium labelled leukocyte excretion in the assess- ment of disease activity in Crohn's disease. Gastroenterology 1983;85:1333-9.

7 Saverymuttu SH, Peters AM, Reavy HJ, Danpure HJ, Osman S, Lavender JP. Lung transit of 111-indium labelled granulocytes-relationship to labelling techniques. Scand J Haemtol 1983;30:151-60.

8 Gray HW, Cuthbert I, Richards JR. Clinical imaging with 111 -indium-leucocytes. Uptake in bowel infarction. J Nucl Med 1981;22:701-2.

9 Raptopolous V, Doherty PW, Goss TP, et al. Acute osteomyelitis. Advantages of white cell scans in early detection. AJR 1982;139:1077-82.

10 Anderson JR, Spence RAJ, Laird JD, Ferguson WR, Kennedy TL. Initial experience with indium-111autologous leucocyte imaging in patients with acute pancreatitis. Br Med J 1983;287:637-8.

11 Wilson DG, Seabold JE, Lieberman LM. Detection of aorto arterial graft infections by leukocyte scintigraphy. Clin Nucl Med 1983;8:421-3.

12 Forstrom LA, Loken MK, Cook A, et al. Indiumlabelled leukocytes in the diagnosis of rejection and cystomeyelovirus infection in renal transplant patients. Clin Nucl Med 1981;6:146-9.

13 Peters AM, Saverymuttu SH, Reavy HJ, Danpure HJ, Osman S, Lavender JP. Imaging inflammation with 111-In troplonate labelled leucocytes. $\mathrm{J} \mathrm{Nucl} \mathrm{Med}$ 1983;24:39-44.

14 Lavender JP, Irvine H, Armstrong JD. Krypton-81m ventilation scanning: acute respiratory disease. $A J R$ 1981;136:309-16.

15 Buescher S, Gallin J. Leukocyte transfusions in chronic granulomatous disease. New Engl J Med 1982;307:800-3.

16 Lichter JP, Konopkar G, Hartman MT, Moser KM, Sprag RG. The in-vivo behaviour of granulocytes labelled with indium-111 in a canine model of pneumoccal pneumonia. Am Rev Respir Dis 1984;129:602-6. 